\title{
A FOS protein is present in a complex that binds a negative regulator of $M Y C$
}

\author{
Nissim Hay, ${ }^{1}$ Masato Takimoto, ${ }^{2}$ and J. Michael Bishop ${ }^{1}$ \\ ${ }^{1}$ Department of Microbiology and Immunology and the G.W. Hooper Foundation, University of California, San Francisco, \\ California 94143 USA; $^{2}$ Laboratory of Pathology, National Cancer Institute, National Institutes of Health, Bethesda, Maryland \\ 20892 USA
}

Regulation of the human proto-oncogene MYC apparently plays an important role in cellular proliferation and the genesis of diverse tumors. Transcription from MYC is governed principally by two promoters known as $\mathbf{P 1}$ and P2. Previously we have detected a negative regulator of these promoters upstream of MYC. We now report that this regulator comprises no more than 26 bp of DNA, with sequence that resembles the regulators of at least two other genes, and we describe nuclear factors that interact with the regulator. Nuclear extracts from human cells form three distinctive complexes with the negative regulator. One of these complexes includes the product of the proto-oncogene FOS or an antigenically related protein, and the FOS protein may, in turn, be associated with the product of the proto-oncogene IUN. Similarly, FOS and IUN proteins produced by translation in vitro bind cooperatively to the negative regulator. These results raise the possibility that FOS and IUN participate in the regulation of MYC.

[Key Words: Transcription; proto-oncogene; oncogene; IUN]

Received November 28, 1988; revised version accepted January 25, 1989.

The expression of the proto-oncogene $M Y C$ appears to be involved in maintaining the cell's capacity for proliferation. Transcription from $M Y C$ is increased during the response of cells to a variety of growth factors and mitogens (Greenberg and Ziff 1984; Kelly et al. 1983; Greenberg et al. 1985; Dean et al. 1986; Levine et al. 1986), whereas transcription of the gene is decreased during differentiation of the cells to a nonproliferative state /Grosso and Pitot 1985; Bentley and Groudine 1986; Eick and Bornkamm 1986; Endo and Nadal-Ginard 1986; Ramsay et al. 1986; Siebenlist et al. 1988). Regulation of transcription from $M Y C$ is mediated by changes in both the elongation and initiation rate of transcription /Greenberg and Ziff 1984; Greenberg et al. 1985; Bentley and Groudine 1986; Nepveu et al. 1987; Siebenlist et al. 1988). Disruption of the normal control of the gene is associated with the development of diverse types of tumors and transformation of cells in tissue culture (Cole 1986; Cory 1986; Small et al. 1987).

We have begun an examination of the mechanisms controlling $M Y C$ transcription by focusing on regulatory sequences within the 5 -flanking region of the human MYC gene. In previous studies we found that the nucleotide sequences between residues -293 and +513 are sufficient for strong and accurate transcription from the two principal promoters for the gene, $\mathrm{P} 1$ and $\mathrm{P} 2(+1$ is the site of initiation for Pl) (Hay et al. 1987). We have defined several elements that modulate the activities of the two promoters: a region that alone can sustain activity of P1 $(-101 /-293)$; two domains that exert posi- tive effects on both $\mathrm{P} 1$ and $\mathrm{P} 2(-353 /-1257$ and $-1257 /-2329$; and a negative regulator that acts on expression from both promoters $(-293 /-353)$.

Within the region $-293 /-353$, we identified a binding site for nuclear protein or proteins (Hay et al. 1987). The binding site encompasses 26 bp with an ATrich core region, overlapped and flanked by inverted repeats of eight residues. Now, we have examined in greater detail the function and the protein-binding properties of the 26 -bp region. We have found that the $26-b p$ DNA element is sufficient to exert a negative effect on expression from both $M Y C$ promoters and thus have termed it the $M Y C$ negative regulatory element (MYCNRE). MYC-NRE forms three complexes with proteins from nuclear extracts of HeLa cells. One of these complexes contains the product of the proto-oncogene FOS or a closely related protein and also may contain the protein encoded by IUN and/or other components of the transcription factor AP-1 (see Rauscher et al. 1988a,b Sassone-Corsi et al. 1988a). Using translation in vitro, we have shown that the FOS protein fails to bind by itself to MYC-NRE, whereas cotranslated FOS and IUN bind cooperatively to $M Y C$-NRE and form a specific protein-DNA complex.

Like FOS and IUN, MYC belongs to a group of genes whose expression is induced during the mitotic activation of quiescent cells. Expression of FOX and $J U N$ is induced rapidly after serum stimulation of growth-arrested cells and is followed by induction of MYC expression. The work presented here sustains this idea by dem- 
onstrating that the products of $F O S$ (and perhaps $I U N$ ) apparently bind to a regulatory element upstream of $M Y C$.

\section{Results}

\section{A 26-bp region that inhibits transcription from MYC promoters}

In previous studies we found that a 60 -bp region between nucleotides -293 and -353 (where +1 is the transcription start site for the P1 promoter) inhibits transcription from the MYC promoters P1 and P2 (Hay et al. 1987). Within this region (between nucleotides -318 and -343 ), we identified a DNA-binding site for a nuclear protein, or proteins, from HeLa cells (Hay et al. 1987). To determine whether this DNA-binding site is sufficient to inhibit transcription from $M Y C$ promoters, we constructed a plasmid in which the 26-bp region between nucleotides -318 and -343 was linked to nucleotide -293 . (For a detailed description of the plasmid, see Materials and methods). This plasmid was designated as $-343 \Delta-293 /-318$ (Fig. 1A, construction b).

The plasmid $-343 \Delta-293 /-318$ and other $5^{\prime}$ deletion mutants (Fig. 1A) were transfected into Ltk ${ }^{-}$cells. Polyclonal populations of stably transfected cells that contained and expressed the various chimera were established. RNA analysis was performed with the RNase protection assay (Fig. 1B). The highest level of expression from the MYC promoters $\mathrm{P} 1$ and $\mathrm{P} 2$ was obtained with the $5^{\prime}$ deletion mutant -293 (Fig. 1B, lane 4); a level of expression of approximately twofold lower was obtained with the 5 '-deletion mutant -321 (Fig. 1B, lane 3). However, a marked decrease of expression from both P1 and P2 promoters was obtained with the plasmid $-343 \Delta-293 /-318$. The relative inhibition of transcription obtained with the deletion mutant $-343 \Delta-293 /-318$ was comparable to that obtained with the $5^{\prime}$-deletion mutant -353 (Fig. 1B, lanes 1,2,4). In agreement with our previous studies, the level of expression by mutant -353 was $\sim 10$-fold lower than that achieved with mutant -293 (Hay et al. 1987). These results indicate that the region between nucleotide -318 and -343 , which represents a binding site for nuclear protein(s) (Hay et al. 1987), is sufficient to inhibit MYC promoters $\mathrm{P} 1$ and $\mathrm{P} 2$.

\section{Binding of three protein complexes to MYC-NRE}

We used a 26-bp synthetic duplex that contains the sequence between nucleotides -318 and -343 (MYCNRE in Fig. 2) to search for binding to protein factors. The radiolabeled 26-bp double-stranded oligomer was incubated with nuclear extract from HeLa cells in the presence of nonspecific competitor poly[d(I-C)]. ProteinDNA complexes were separated from free DNA by electrophoresis in a nondenaturing gel (Fried and Crothers 1981; Strauss and Varshavsky 1984). The MYC-NRE oligomer formed three complexes with nuclear protein, as demonstrated by retarded mobility, relative to that of the free DNA (Fig. 3). The three DNA-protein complexes were designated $a, b$, and $c$.

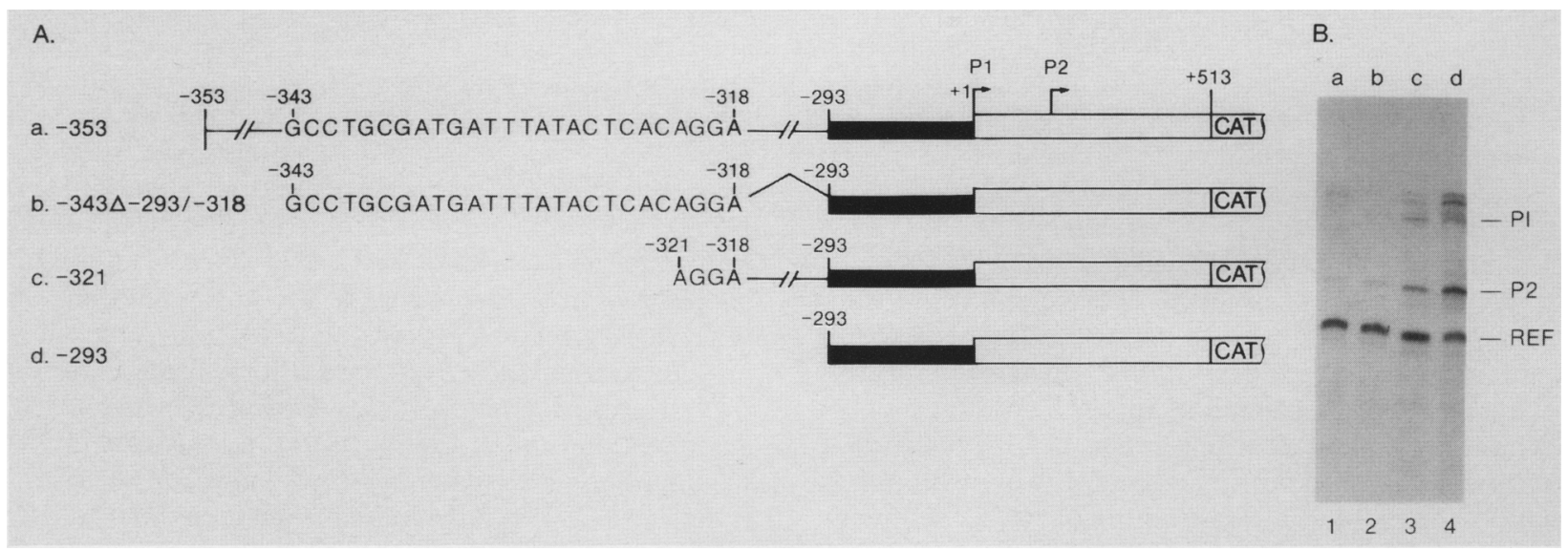

Figure 1. Control of MYC promoters by upstream sequences. (A). Diagram of DNAs introduced into cells. Arrowheads indicate the sites for initiation of transcription controlled by promoters P1 and P2; The coordinates for MYC are defined relative to the site of initiation for P1 $(+1)$. $(B)$. Quantitation of RNA by RNase protection assay. Polyclonal lines of $\mathrm{Ltk}^{-}$cells bearing the DNAs described in $A$ were established using cotransfection with hygromycin B. Transcripts derived from P1 and P2 were then detected by hybridization with RNA fragment synthesized with Sp6 polymerase and subsequent hydrolysis with RNase A and Tl (Hay et al. 1987). The protected fragments were analyzed by electrophoretic fractionation on denaturing acrylamide gels. RNA fragments representing initiation by $\mathrm{P} 1$ and $\mathrm{P} 2$ are labeled. An RNA probe for transcripts derived from the cotransfected hygromycin B gene served as an internal standard (REF). Lanes are marked according to the diagram in $A$. 


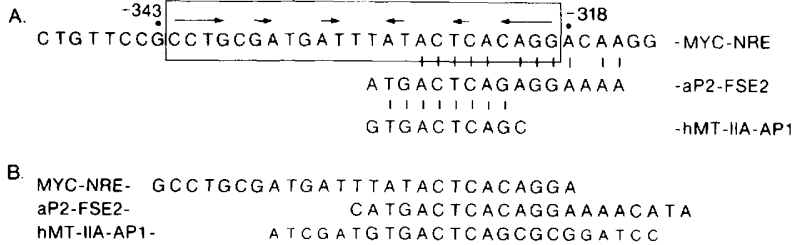

Figure 2. Similarities among $M Y C-N R E, F S E 2$, and $h M_{\mathrm{II}} \mathrm{A}$ AP1. (A). Comparison of MYC-NRE, FSE2 of the aP2 gene, and $\mathrm{hM}_{\mathbf{I I}} \mathrm{A}-\mathrm{AP} 1$. The framed sequence indicates the portion of MYC-NRE responsible for binding nuclear factors. Arrowheads indicate the dyad symmetry within MYC-NRE. Identities between different sequences are indicated by vertical lines. $(B)$. Sequence of double-stranded synthetic oligonucleotides used for the gel retardation assays. Smaller size letters indicate nucleotides that are not part of the binding site but were added to the synthetic oligonucleotide for stability of duplexes.

\section{A nuclear protein complex that binds to MYC-NRE and other regulators of transcription}

We compared the sequence of $M Y C$-NRE to the sequence of another negative regulator, upstream of the adipocyte-specific gene aP2 (Distel et al. 1987). This sequence, FSE2, is probably responsible for repressing expression of aP2 in preadipocyte cells. Comparison of the FSE2 and MYC-NRE sequences revealed a region of 13

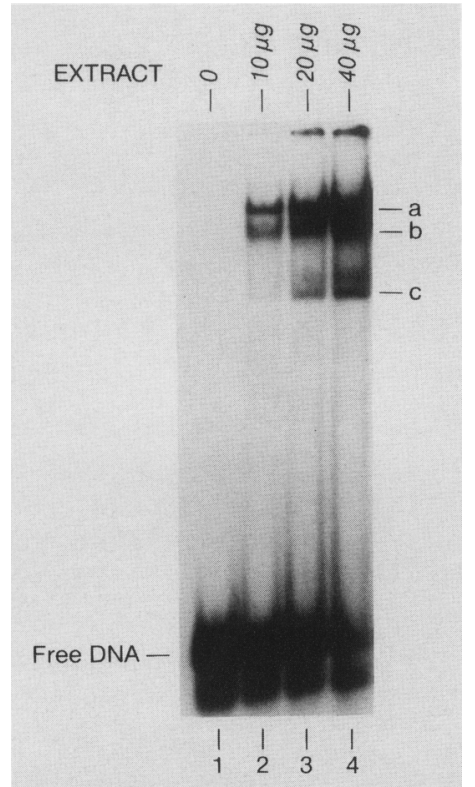

Figure 3. Binding of nuclear factors to $M Y C$-NRE. Approximately $0.2 \mathrm{ng}$ of synthetic double-stranded oligonucleotide, representing MYC-NRE and end labeled with ${ }^{32} \mathrm{P}$, was incubated with increasing amounts of HeLa nuclear extract, followed by electrophoretic fractionation in an acrylamide gel (for details, see Materials and methods). bp within FSE2 that contains the recognition site for the transcription factor AP-1 and has only two mismatches with the sequence of $M Y C$-NRE between nucleotides -315 and -327 (Fig. 2A). FSE2 also resembles the site upstream of the human metallothionein IIA gene that binds a complex of transcription factors, including the products of the proto-oncogenes IUN (known also as the AP-1 factor) and FOS (Fig. 2A) (Angel et al. 1987; Lee et al. 1987; Chiu et al. 1988; Rauscher et al. 1988a; Sassone-Corsi et al. 1988b). This site is designated $\mathrm{hMT}_{\mathrm{I}} \mathrm{A}$ AP1. To test whether common nuclear protein factors bind to the three different elements (MYC-NRE, FSE2, and $\mathrm{hMT}_{\mathrm{n}} \mathrm{A}-\mathrm{AP} 1$ ), we performed DNA-binding experiments and competition assays, using synthetic oligomers representing the three binding sites (Fig. 2B).

The ability of $M Y C$-NRE to compete specifically for the binding of protein to FSE2 was determined first (Fig. 4). Incubation of the labeled FSE2 double-stranded oligomer with HeLa nuclear extract, followed by the gel retardation assay, revealed formation of two proteinDNA complexes (I and II in Fig. 4, lane 1). Complex I is equivalent to the complex $\mathrm{b}$ that forms with MYC-NRE DNA (Fig. 6); complex II is equivalent to complex c (Fig. 6; N. Hay, unpubl.). Formation of complex II was inhibited efficiently when the binding assay was done in the presence of increasing excess of the cognate oligomer (Fig. 4, lanes 2-5). Formation of the same protein-DNA complex also was inhibited with similar efficiency by using MYC-NRE as a competitor (Fig. 4, lanes 6-10). To demonstrate the specificity of the competition, the DNA-binding assay was performed in the presence of a

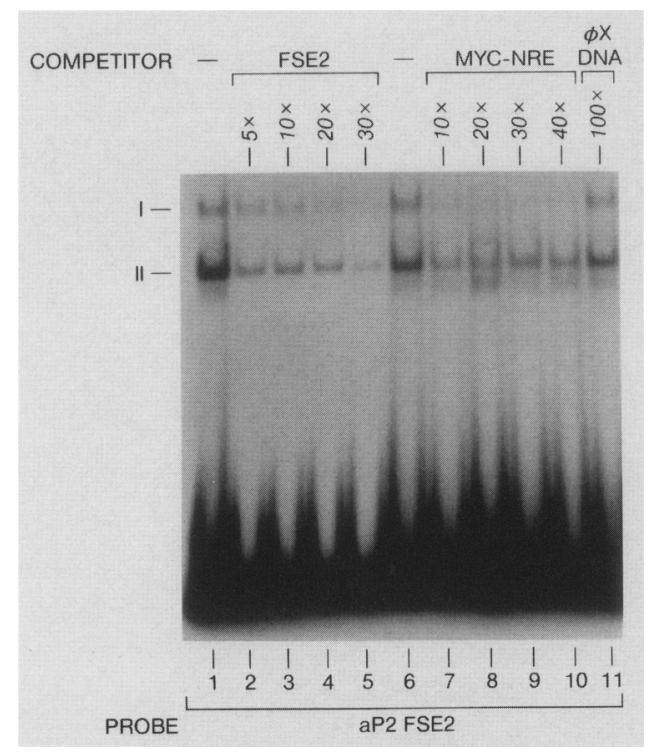

Figure 4. MYC-NRE competes with FSE2 for binding of a nuclear factor. Approximately $0.2 \mathrm{ng}$ of ${ }^{32} \mathrm{P}$-labeled FSE2 was incubated with HeLa nuclear extract in the absence or presence of the indicated excess of unlabeled FSE2, MYC-NRE, or $\phi X 174$ HaeIII fragments. 
100 -fold excess of $\phi X 174$ DNA. No significant interference with the formation of the protein-DNA complexes was observed (Fig. 4, lane 11).

Then we performed the reciprocal competition assay to determine whether FSE2 and $\mathrm{hMT}_{\mathrm{II}} \mathrm{A}$-AP1 could compete for binding to the MYC-NRE. As shown in Figure 5, lanes 1-3, the formation of protein-DNA complexes a and $\mathrm{b}$ with MYC-NRE was inhibited in the presence of excess amounts of the cognate oligomer. Protein-DNA complex c appeared to result from a nonspecific interaction, as the formation of this complex was not competed efficiently (see Figs. 4 and 5; M. Takimoto and D. Levens, unpubl.). In the presence of FSE2 or $\mathrm{hMT}_{\mathrm{II}} \mathrm{A}-\mathrm{AP1}$ as competitors, a marked decrease in the formation of protein-DNA complex $b$ was observed without significant inhibition of formation of protein-DNA complex a (Fig. 5, lanes 4-9).

The results of the competition assays suggested that the same nuclear proteins that bind to FSE2 and ${ }^{h M T} \mathrm{~T}_{\mathrm{II}} \mathrm{A}-\mathrm{APl} \mathrm{l}$ also participate in the formation of protein-DNA complex b with MYC-NRE. We obtained further evidence for this assumption by carrying out the DNA-binding assays with nuclear extracts from the neuroblastoma cell line Kelly. Formation of complex b could not be detected with these extracts (Fig. 6, lanes

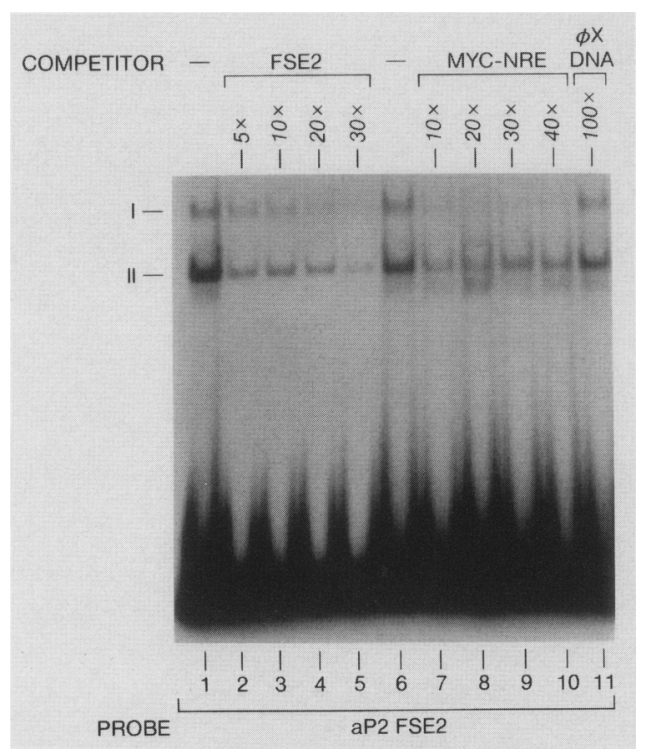

Figure 5. FSE2 and hMT ${ }_{\mathrm{II}} \mathrm{A}-\mathrm{AP} 1$ compete with $M Y C-\mathrm{NRE}$ for binding of a nuclear factor. Approximately $0.2 \mathrm{ng}$ of ${ }^{32} \mathrm{P}$-labeled $M Y C-N R E$ was incubated with HeLa nuclear extract in the absence or presence of the indicated excess of unlabeled $M Y C$ NRE, FSE2, or hMT $\mathrm{T}_{\Pi} \mathrm{A}-\mathrm{AP} 1$.

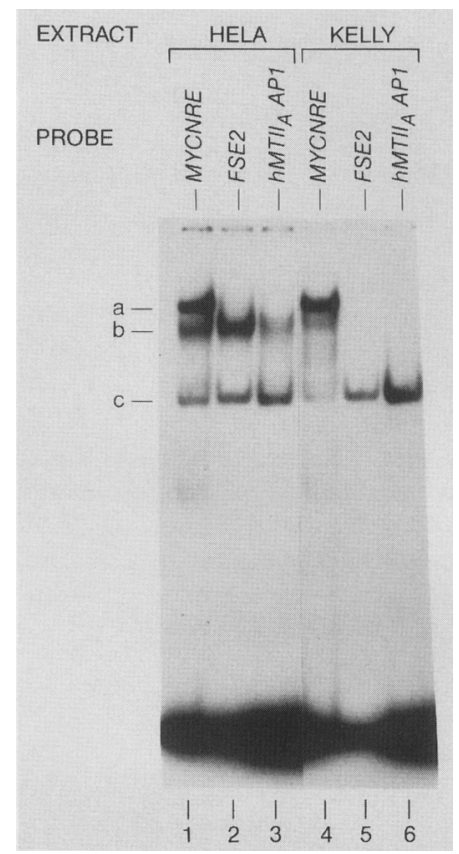

Figure 6. Gel retardation assay with $\mathrm{HeLa}$ and Kelly nuclear extracts. MYC-NRE, FSE2, or hMT ${ }_{\text {II }} \mathrm{A}-\mathrm{AP} 1$, labeled with ${ }^{32} \mathrm{P}$, was incubated with $10 \mu \mathrm{g}$ of either HeLa or Kelly nuclear extract, followed by electrophoretic fractionation.

1,4). The corresponding protein-DNA complex with FSE2 and $h M T_{n}$ A-AP1 also was not present when Kelly extract was used (Fig. 6 , lanes $2,3,5,6$ ). These results sustain the view that similar or identical proteins contribute to the formation of complex b with MYC-NRE, FSE2, and $\mathrm{hMT}_{\mathrm{II}} \mathrm{A}-\mathrm{AP} 1$.

FOS protein or a related antigen is a component of a protein complex that binds to MYC-NRE

It was shown previously that FSE2 and $\mathrm{hMT}_{\mathrm{I}} \mathrm{A}-\mathrm{AP} 1$ binds FOS protein specifically, in association with $J U N$ protein-otherwise known as the nuclear factor AP-1 (Bohmann et al. 1987; Chiu et al. 1988; Rauscher et al. $1988 \mathrm{~b}$; Sassone-Corsi et al. 1988b). The results of the competition experiments described above led us to examine whether a FOS protein binds to MYC-NRE. We tried to inhibit the binding of nuclear factors to $M Y C$ NRE by preincubation of the extract with antibodies directed against the FOS protein, following the strategy described previously by Spiegelman and his colleagues (Distel et al. 1987). The nuclear extract was preincubated with antibodies prior to addition of the labeled DNA. FOS-specific antibodies interfered with the binding of protein complex to MYC-NRE and specifically abolished formation of DNA protein complex $b$ 
(Fig. 7A,B, lanes 1,2). The inhibition by the antibody was specific because $M Y C$ antibodies or other unrelated antibodies caused no significant inhibition of the binding (Fig. 7A, lane 3; N. Hay, unpubl.). Furthermore, when the preincubation with the affinity-purified FOS antibodies was done in the presence of the peptide against which the antibody was made, formation of DNA protein-complex b was restored (Fig. 7B, lane 3). Similar results were obtained when the FSE2 oligomer was used as a probe in the DNA-binding assay (Fig. 7A,B, lanes 4-6), in agreement with what was shown previously (Distel et al. 1987; Rauscher et al. 1988a). The level of inhibition for the binding obtained with FOS antibodies varied from one experiment to the other in a range of $70-90 \%$. However, inhibition of the binding to FSE2 was usually more efficient than that to MYC-NRE (Fig. 7A,B).

We used immunological means to detect FOS protein directly in complex b. HeLa nuclear extract was incubated with unlabeled MYC-NRE, followed by electrophoresis in a nondenaturing gel. The retarded complexes were transferred to nitrocellulose paper and probed with FOS antibodies. The immunoreactive band comigrated with protein-DNA complex b (Fig. 8).
We also were able to immunoprecipitate the complex with FOS antibodies. The DNA-binding assay with the labeled oligonucleotides was done as described previously. The protein-DNA complexes were then incubated with FOS antibodies, and the immunoprecipitate was applied to a denaturing gel. When the binding assay was done with HeLa nuclear extract and immunoprecipitation was performed with MYC antibodies as a control, no labeled DNA could be detected in the gel (Fig. 9A, lanes 1,6$)$. No labeled DNA could be immunoprecipitated when Kelly extract was used in the DNAbinding assay, and FOS antibodies were used for the immunoprecipitation (Fig. 9A, lanes 2,5). The labeled DNA could be immunoprecipitated only when Hela nuclear extract was used in the DNA-binding assay and immunoprecipitation was performed with FOS antibodies (Fig. 9A, lanes 3,4). Therefore, it appears that although preincubation of the extract with FOS antibodies prevents complex formation, the antibody can detect complexes once they have formed. However, the recovery of intact protein-DNA complex by immunoprecipitation with FOS antibodies is not very efficient, as the yield of the immunoprecipitated DNA is low relative to input DNA (Fig. 9B).
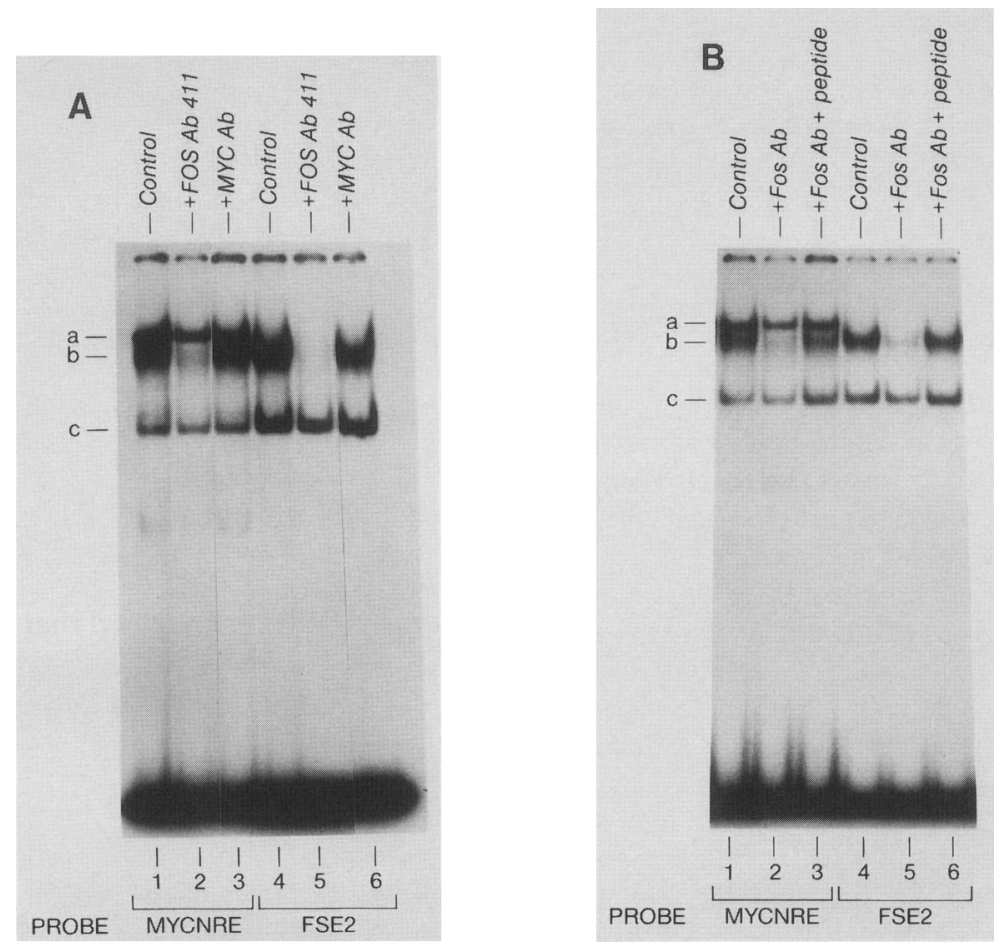

Figure 7. FOS antibodies inhibit binding of nuclear factors to MYC-NRE or FSE2. Aliquots (10 $\mu \mathrm{g}$ ) of HeLa nuclear extract were preincubated with no addition or with FOS antibodies. MYC-NRE or FSE2 oligonucleotides labeled with ${ }^{32} \mathrm{P}$ were added, and incubation continued for an additional $30 \mathrm{~min}$ (for details, see Materials and methods). Protein-DNA complexes then were fractionated by electrophoresis. (A) Preincubation of $10 \mu \mathrm{g} \mathrm{HeLa}$ nuclear extract with no addition (control), or with addition of $F O S$ monoclonal antibodies (+FOS Ab411) or MYC antibodies ( $M Y C \mathrm{Ab}$ ). (B) Preincubation of $10 \mu \mathrm{g} \mathrm{HeLa}$ extract with no addition (control), with addition of $1 \mu \mathrm{g}$ of antibodies directed against the M peptide of FOS protein (+FOS Ab), or with $1 \mu \mathrm{g} F O S$ M peptide antibodies and 5 $\mu g$ of $M$ peptide (+ FOS $\mathrm{Ab}+$ peptide). 


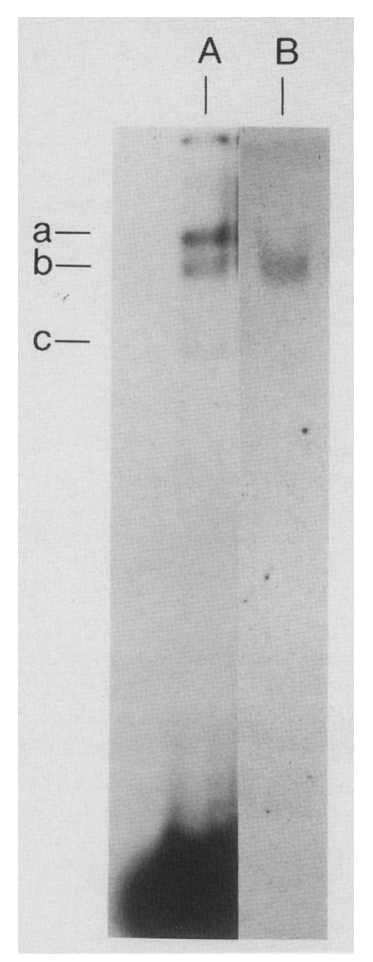

Figure 8. Presence of $F O S$ protein or a related antigen in a complex formed with MYC-NRE. (Lane $A$ ) HeLa nuclear extract $(10 \mu \mathrm{g})$ was incubated with ${ }^{32} \mathrm{P}-$ labeled MYC-NRE, and protein-DNA complexes were resolved by electrophoresis. (Lane B) Protein-DNA complexes were resolved after incubation of $20 \mathrm{ng}$ unlabeled MYC-NRE with $100 \mu \mathrm{g}$ of HeLa nuclear extract. The complexes were then transferred from the gel to nitrocellulose paper and probed with FOS M peptide antibodies.

\section{Cooperative binding of FOS and JUN protein to the MYC-NRE}

FOS and IUN proteins form a complex that binds to AP-1-like binding sites (Chiu et al. 1988; Franza et al. 1988; Rauscher et al. 1988b; Sassone-Corsi et al. 1988b). Therefore, we tried to determine whether affinity-purified AP- 1 can bind to the MYC-NRE. The DNA-binding assay was performed with AP-1 that had been isolated by chromatography on an affinity column bearing TPA-responsive elements of the collagenase gene (kindly provided by Beth Allegretto and Michael Karin). As shown in Figure 10, lane 2, the preparation of AP-1 bound to MYC-NRE, forming a complex that comigrated with protein-DNA complex b (Fig. 10, lanes 1,2). When the AP-1 preparation was preincubated with FOS antibodies, the binding activity was reduced significantly (Fig. 10, lane 3). However, when the preincubation with antibody was done in the presence of the cognate peptide, binding activity could be restored (Fig. 10, lane 4). We attribute these findings to the copurification of AP-1 and FOS protein, described previously (Rauscher et al. 1988b). Because the FOS protein forms high-affinity complex with components of AP-1 (Chiu et al. 1988; Rauscher et al. 1988b; Sassone-Corsi et al. 1988b), we infer that this complex binds $M Y C-\mathrm{NRE}$ and that the binding may negatively regulate activity of the $M Y C$ promoters $\mathrm{P} 1$ and P2 (see Discussion).

The product of the JUN proto-oncogene is a major component of AP-1 preparations and generally is equated to AP-1 (Curran and Franza 1988). Therefore, we used translation in vitro to assess the ability of FOS and IUN proteins to bind MYC-NRE (Fig. 11). Neither gene product bound the DNA in isolation; but when combined, the products of FOS and IUN formed a complex with the oligonucleotide of MYC-NRE with similar, if not identical, electrophoretic mobility to that of the complex (b) formed with nuclear extracts (Fig. 11; data not shown). These results sustain our view that the products of FOS and IUN are principal components of the protein complex that binds $M Y C-\mathrm{NRE}$.

\section{Identification of the nucleotide sequence required for binding protein complex to MYC-NRE}

MYC-NRE is composed of inverted repeats of eight residues (Fig. 2A) and forms three complexes with nuclear proteins (Fig. 3). Formation the protein-DNA complex c appears to occur with only limited specificity (see

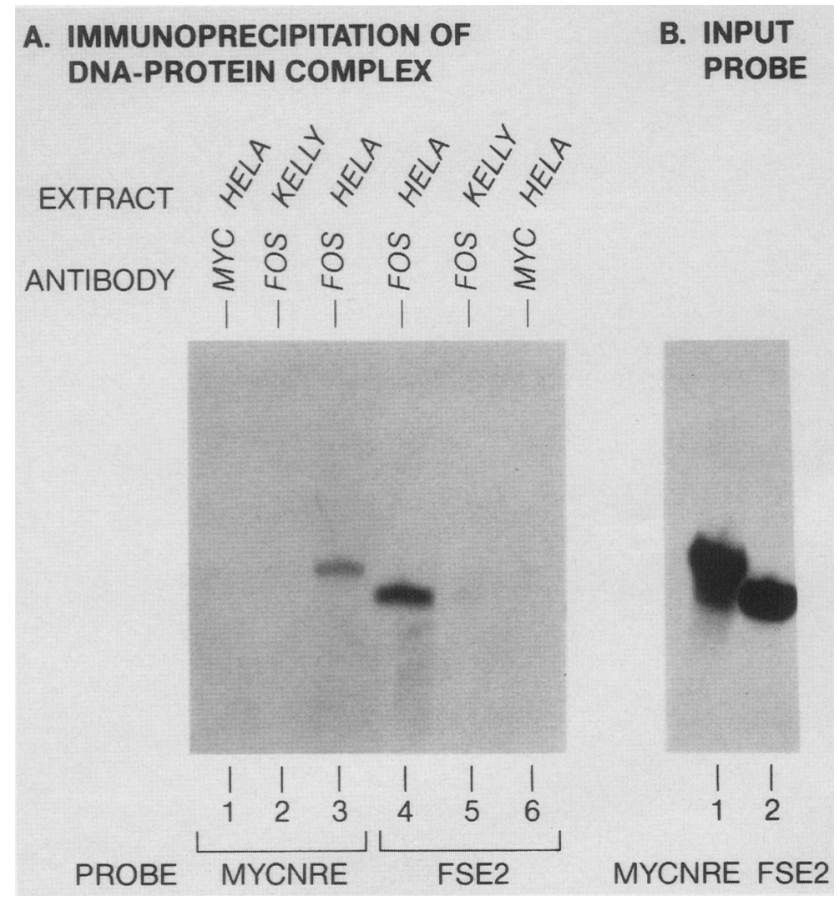

Figure 9. Immunoprecipitation of complexes containing NRE or FSE2 by FOS antibodies. $(A) M Y C$-NRE or FSE2, labeled with ${ }^{32} \mathrm{P}$, was incubated with either HeLa or Kelly nuclear extracts, followed by immunoprecipitation of protein-DNA complexes (for details, see Materials and methods). The immunoprecipitates were applied to a denaturing acrylamide gel. The autoradiograph was exposed for $16 \mathrm{hr}$ at $-70^{\circ} \mathrm{C}$. (B) Quantities of ${ }^{32} \mathrm{P}$ labeled MYC-NRE or FSE2 identical to those used in $A$ were used in a binding assay without immunoprecipitation. The autoradiograph was exposed for $30 \mathrm{~min}$ at $-70^{\circ} \mathrm{C}$. 
above), whereas formation of protein-DNA complexes a and $b$ is specific. As shown in Figures 7-10, complex b contains FOS protein and may be identical to the complex that forms with FSE2 and $\mathrm{hMI}$ A-AP1. The portion of $M Y C-\mathrm{NRE}$ that corresponds to the AP-1 binding site and to FSE2 is limited to residues -315 to -327 (Fig. 2A). In the DNA-binding assays described above, however, we used double-stranded oligonucleotide that contained the sequence between -318 and -343 (Fig. 2B). To better define the DNA sequence that forms complex b, we performed deletion analysis on MYC-NRE (Fig. 12).

The right hand of the dyad symmetry in MYC-NRE (between nucleotides -312 and -329 , or dll in Fig. 12) spans the sequence shared with FSE2 (Figs. 2A and 12A). We found that this domain was not sufficient for formation of either complex a or b (which contains FOS protein), although the nonspecific complex c still formed. A double-stranded oligonucleotide that spanned the left hand and part of the right hand of the dyad symmetry also was not sufficient for formation of either complex a or b (dl2 in Fig. 12), although formation of complex $\mathrm{c}$ was again apparent (Fig. 12B, lane 3). Double-stranded DNA comprising the sequence between nucleotides -313 and -338 , which contains the right hand of the dyad sym-

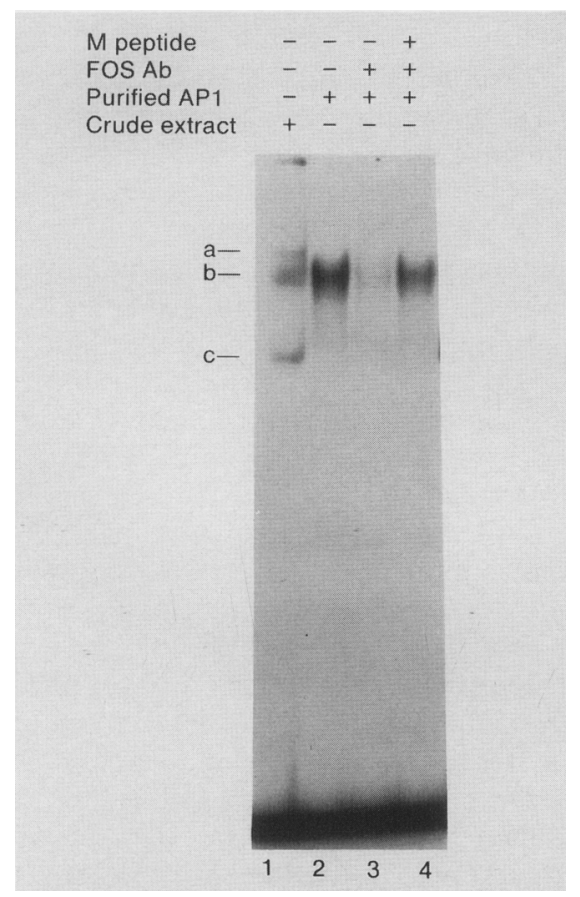

Figure 10. Binding of affinity-purified AP-1 to $M Y C$-NRE and inhibition of the binding by FOS antibody. Binding of HeLa nuclear extract or affinity-purified AP-1 to labeled MYC-NRE was performed as described in Fig. 9. Preincubation of affinity-purified AP- 1 with no addition, with addition of $1 \mu \mathrm{g}$ of FOS M peptide antibody, or with $1 \mu \mathrm{g}$ of FOS $\mathrm{M}$ peptide antibody and 5 $\mu \mathrm{g} M$ peptide was performed at $4^{\circ} \mathrm{C}$ for $2 \mathrm{hr}$.

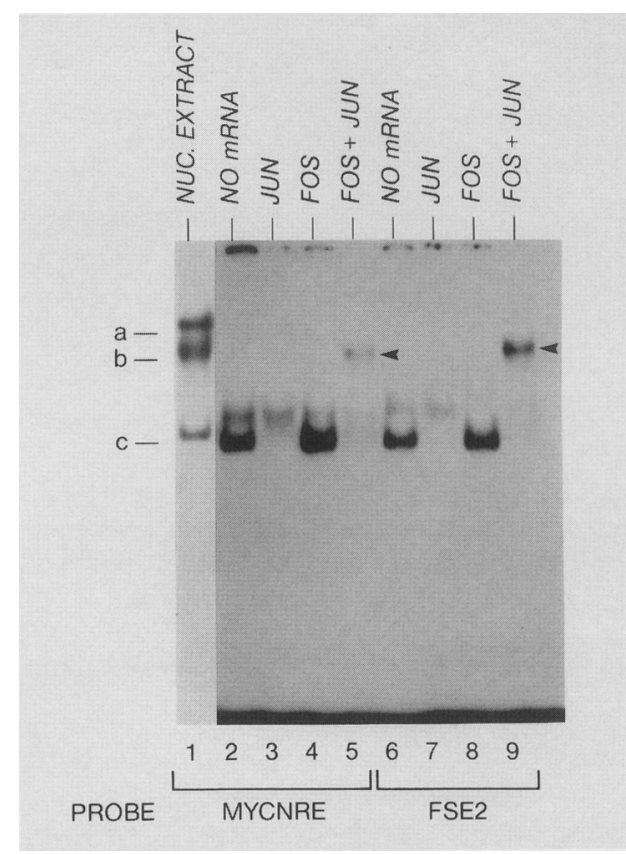

Figure 11. Binding of FOS and $I U N$ proteins to $M Y C-N R E$ and FSE2. MYC-NRE or FSE2, labeled with ${ }^{32} \mathrm{P}$, was incubated with proteins synthesized in vitro and assayed by gel retardation analysis. (Lane 1) HeLa nuclear extract; (lanes 2,6) rabbit reticulocyte lysate with no added mRNA; (lanes 3,7 ) JUN translated in vitro; (lanes 4,8) FOS translated in vitro; (lanes 5,9) cotranslation of $F O S$ and $I U N$. The specific complex of FOS/IUN with DNA is indicated by arrows. The lower bands are related to nonspecific binding of proteins from the reticulocyte lysate.

metry and part of the left hand (dl3 in Fig. 12), was sufficient for formation of both complexes a and b (Fig. 12B, lane $\left.4\right|_{\text {; }}$ however, the relative formation of complex $b$ versus complex a was less efficient, in comparison with the binding to the intact dyad symmetry sequence (Fig. $12 \mathrm{~B}$, lanes 1,41 . Thus, the DNA sequence between nucleotides -318 and -338 is necessary and sufficient for the formation of complexes a and $b$. Preliminary results of contact point analysis revealed that the TGA on both DNA strands (underlined in Fig. 12A) is important for the formation of complex $\mathrm{b} / \mathrm{M}$. Takimoto and $\mathrm{D}$. Levens, unpubl.).

\section{Discussion}

A negative regulator upstream of the promoters for human MYC

In previous studies we showed that nucleotide sequences between residues -293 and +513 in $M Y C$ are sufficient for strong activity of the two principal promoters for the gene, P1 and P2 (Hay et al. 1987). We defined several elements that modulate the activities of the two promoters: a region that can sustain alone the activity of $\mathrm{Pl}$, between nucleotides -101 and -293 ; 


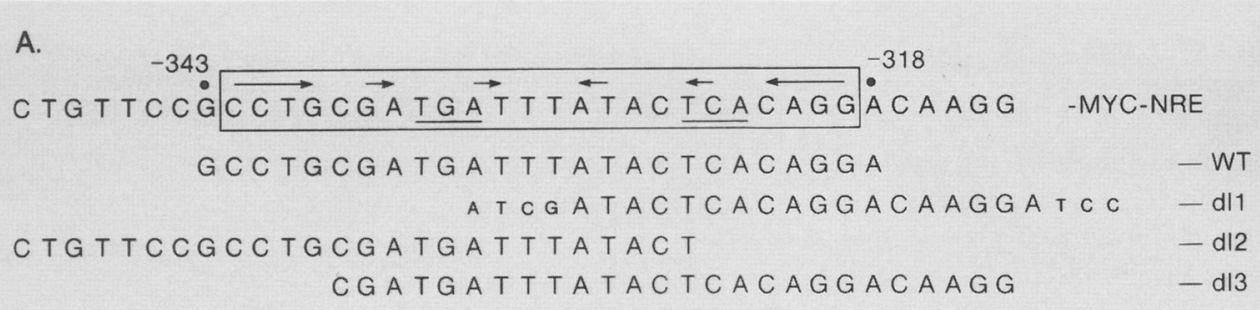

B.

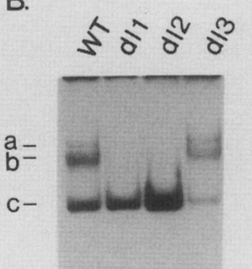

Figure 12. Characterization of $M Y C$-NRE by deletion analysis. $(A)$ The sequence of $M Y C$-NRE proper between -318 and -343 (in frame) and flanking sequences. Arrowheads indicate the dyad symmetry; underlining designates the putative points of contact with protein factors. (WT) Sequence of the double-stranded synthetic oligonucleotide used in previous assays; ( $\mathrm{dl} 1$, d $\mathrm{dl} 2$, and dl3) sequences of oligonucleotides from different regions of the MYC-NRE used for the gel retardation assay. Small size letters indicate nucleotides that were added to the synthetic oligonucleotides and are not present in $M Y C$-NRE. $(B)$ Gel retardation assay with HeLa nuclear extract and labeled synthetic double-stranded oligonucleotides, described in $A$.

two domains that exert a positive effect on both $\mathrm{Pl}$ and P2 $(-353 /-1257$ and $-1257 /-2329)$; and a negative regulator that acts on both promoters $(-293 /-353)$.

The negative regulator can operate as an isolated unit in proliferating cells, although the inhibitory effect can be overridden by positive regulators upstream of -353 (Hay et al. 1987), as well as by a heterologous transcriptional enhancer such as that of the early region of the SV40 genome (N. Hay and J.M. Bishop, unpubl.). Here, we have shown that the negative regulator resides within a region that was found to be protected from DNase digestion after incubation with HeLa nuclear extract (Hay et al. 1987). This 26-bp region, between nucleotides -318 and -343 , is sufficient to exert negative regulation on promoters $\mathrm{P} 1$ and $\mathrm{P} 2$ of $M Y C$. The sequence of the protein-binding site within the $M Y C-\mathrm{NRE}$ is comprised of AT-rich core regions, flanked and overlapped by inverted repeats of eight residues.

Previously, we reported some similarities between MYC-NRE and the negative regulator of human $\beta$ interferon (Hay et al. 1987), but we have since noticed more significant homology between the MYC-NRE and FSE2 -a negative regulator upstream of the adipocyte-specific gene, aP2 (see Fig. 2A). FSE2 encompasses $\sim 21 \mathrm{nu}-$ cleotides, which include a recognition site for the transcription factor AP-1 (Distel et al. 1987; Rauscher et al. 1988a). Comparison of FSE2 and $M Y C$-NRE revealed a region of 13 bp within FSE2 that contains the AP-1 recognition site and has only two mismatches with the MYC-NRE sequence.

The negative regulator we describe here is probably not the only one that acts on transcription from MYC. Recently, another negative regulator has been reported within the first intron of human MYC (Zajac-Kaye et al. $\left.1988\right|_{;}$in addition, a block in elongation of transcription also contributes to repression of the gene during differentiation (Bentley and Groudine 1986; Eick and Bornkamm 1986; Siebenlist et al. 1988). It is possible that different negative regulators operate in different physiological settings. Alternatively, different regulators may interact with one another to achieve more efficient regu- lation. For example, it would be of interest to determine whether the negative regulator described here can influence the elongation rate of transcription which, in turn, may affect the frequency of premature termination of transcription at the $3^{\prime}$ end of the first exon of $M Y C$ (Bentley and Groudine 1988).

\section{A complex that includes AP-1 and a FOS protein binds MYC-NRE}

Previously, we have provided evidence that nuclear protein or proteins can bind specifically to MYC-NRE (Hay et al. 1987). We did not know how many factors might be involved in the binding or what their nature might be. The resemblance of $M Y C$-NRE to FSE2, together with the finding that FSE2 can bind specifically a protein complex that includes the product of FOS associated with the transcription factor AP-1 (Distel et al. 1987; Rauscher et al. 1988a), encouraged us to examine whether a similar complex could bind to MYC-NRE.

We found that three distinct complexes form between cellular proteins and MYC-NRE. One of these complexes contains $F O S$ protein or an antigenically related protein, and the electrophoretic mobility of the complex is identical to that of complexes formed with either FSE2 or an AP-1-binding site. Formation of this complex also is eliminated by oligonucleotide competitors possessing a known AP-1 binding site. First, there is no evidence to date that the various FOS proteins interact directly with the AP-1 binding site in DNA. Instead, the binding is mediated indirectly by other components of AP-1, such as the product of the proto-oncogene IUN (Chiu et al. 1988; Rauscher et al. 1988b; Sassone-Corsi et al. 1988b). Second, it is likely that all of the FOS proteins in preparations of AP-1 are in highly stable complexes with other proteins (Chiu et al. 1988; Rauscher et al. 1988b; Sassone-Corsi et al. 1988b). Given the heterogeneity of proteins in preparations of AP-1 (for review, see Curran and Franza 1988), we cannot specify which components of the preparations might be collaborating with FOS protein in the binding to DNA studied here. However, 
we suspect that the IUN protein is an essential component of the complex with MYC-NRE: When produced by translation in vitro, the product of FOS cannot bind $M Y C$-NRE unless the product of $J U N$ is also present.

We emphasize that the portion of MYC-NRE shared with FSE2 is not sufficient for the formation of the complex containing FOS protein; the homology between $M Y C$-NRE and FSE2 is limited to the sequence between nucleotides -315 and -327 , but the DNA sequence between nucleotides -327 and -338 is also necessary for efficient binding of the FOS-protein complex.

The transcription factor AP-1 was first identified as a specific trans-activator of genes induced by TPA (Angel et al. 1987; Lee et al. 1987). More recently, it has been shown that in cases where AP-1 plays a role in trans-activation, it is associated with $F O S$ protein, which also is required for efficient trans-activation (Chiu et al. 1988; Sassone-Corsi et al. 1988b; Schonthal et al. 1988). However, in several other cases (FSE2 in adipocytes, the long terminal repeats of HIV, and the FOS promoter), FOS protein appears to be associated with negative regulation of transcription (Distel et al. 1987; Franza et al. 1988; Sassone-Corsi et al. 1988a). Here, we have provided evidence that a complex containing FOS protein binds to a nucleotide sequence upstream of $M Y C$ promoters; the binding sequence mediates negative regulation of transcription from MYC.

At present, we cannot be certain whether it is FOS protein itself or an antigenically related protein that is associated with MYC-NRE (Cohen and Curran 1988). However, three points of evidence suggest to us that authentic FOS protein is involved: (1) antibodies directed against several distinct regions of the FOS protein blocked formation of the complex (Fig. 7); (2) FOS protein produced by translation in vitro bound cooperatively with the IUN product to MYC-NRE (Fig. 11); (3) authentic FOS protein has been isolated from the complex formed by nuclear extracts with MYC-NRE (M. Takimoto and D. Levens, unpubl.).

In reality, two specific complexes form with the MYC-NRE. We have focused on one of these because apparently it forms by the binding of both FOS and JUN proteins. We have not identified any components of the other complex and have no direct evidence as to the role of either of these complexes in the intact cell.

\section{The FOS protein may regulate MYC expression}

The expression of MYC, FOS, and IUN is associated with cellular proliferation. The protein products of these proto-oncogenes may function as nuclear mediators that affect the gene expression in response to signals from an extracellular environment. There is now clear evidence that FOS and IUN proteins are associated with each other and are components of transcription complexes active on several eukaryotic genes (Chiu et al. 1988; Franza et al. 1988; Rauscher et al. 1988a; Sassone-Corsi et al. 1988a,b ; moreover, FOS and $J U N$ may also regulate the expression of each other (Sassone-Corsi et al. 1988a). The data presented here raise an additional pos- sibility: that FOS and JUN proteins may contribute to the regulation of $M Y C$.

The induction of FOS in response to mitogens precedes that of MYC. It is unlikely, however, that FOS expression trans-activates $M Y C$ directly, as the induction of both genes occurs and is stimulated even when the synthesis of new protein is inhibited (Cochran et al. 1984; Muller et al. 1984; Greenberg et al. 1985). Instead, our finding that a complex containing FOS protein binds specifically to a negative regulator upstream of $M Y C$ suggests that the FOS protein may participate in the repression of $M Y C$. Indeed, the induction of $M Y C$ by mitogens begins only after expression of FOS begins to decline (Muller et al. 1984; Greenberg and Ziff 1984; Greenberg et al. 1986). Reciprocal regulation of MYC and $F O S$ also is observed during differentiation of at least some cell types; $M Y C$ expression ceases as those cells differentiate, whereas FOS is activated (Gonda and Metcalf 1984; Muller et al. 1985). Also, it is possible that FOS triggers MYC expression by interfering with a repressor protein that binds specifically to MYC-NRE. Whatever the role of FOS in the regulation of MYC might be, our observation that FOS protein is part of a complex that binds to a sequence upstream of the $M Y C$ promoter implies that there is an interplay of some sort between FOS and MYC and that further studies to explore this interplay are in order.

\section{Materials and methods}

\section{Cells and transfection}

Mouse Ltk ${ }^{-}$cells and HeLa cells were grown in Dulbecco's modified Eagle's medium, supplemented with $10 \%$ fetal calf serum. Kelly cells were grown in RPMI, supplemented with $10 \%$ fetal calf serum.

Transfection of cells was performed using calcium phosphate precipitation (Graham and van der Eb 1973). Stable transfection of $\mathrm{Ltk}^{-}$cells and selection with hygromycin B was carried out as described previously (Hay et al. 1987).

\section{Plasmids and synthetic oligonucleotides}

Plasmids were constructed and prepared as described previously (Hay et al. 1987). The plasmid pBRCAT (Walker et al. 1983) was used to construct $M Y C$-chloramphenicol acetyltransferase (CAT) hybrids. The plasmid $-343 \Delta-293 /-318$ was constructed by insertion of the double-stranded oligonucleotide containing the sequence between -318 and -343 , immediately upstream of nucleotide -293 in the hybrid plasmid -293 MYC-CAT. Orientation of the inserted DNA was determined by sequencing. To create the deletion with 321 bp upstream of the transcription start site, an SfanI restriction site was used. Full details of each construct are available upon request. Synthetic oligomers were purchased from Operon Technologies, Inc. (San Pablo, California). Double-stranded synthetic oligomers were end-labeled with $\left[{ }^{32} \mathrm{P}\right] \mathrm{ATP}$, using T4 polynucleotide kinase (Maniatis et al. 1982).

RNA analysis

Total cellular RNA was isolated and analyzed by RNase protection as described previously (Hay et al. 1987). 


\section{Preparation of nuclear extracts and binding assays}

Nuclear extracts were prepared according to the procedure of Dignam et al. (1983). The nuclear extracts were precipitated with $30 \%$ ammonium sulfate and centrifuged at $25,000 \mathrm{~g}$ for 20 $\mathrm{min}$. The pellet was resuspended in buffer D $20 \mathrm{mM}$ HEPES $/ \mathrm{pH}$ 7.9), $70 \mathrm{~mm} \mathrm{KCl}, 1 \mathrm{~mm} \mathrm{MgCl}_{2}, 0.5 \mathrm{~mm}$ DTT, $0.2 \mathrm{~mm}$ EDTA, and $20 \%$ glycerol]. HeLa nuclear extract $(10 \mu \mathrm{g})$ was preincubated in $20 \mu \mathrm{l}$ of buffer $\mathrm{D}$ in the presence of $1 \mu \mathrm{g}$ poly[d(I-C)] for $10 \mathrm{~min}$ at $4^{\circ} \mathrm{C}$. Double-stranded oligomer $(0.2 \mathrm{ng})$, end-labelled with ${ }^{32} \mathrm{P}$, was added and preincubation at $4^{\circ} \mathrm{C}$ was continued for an additional $5 \mathrm{~min}$, followed by $30 \mathrm{~min}$ of incubation at room temperature. Binding assays with affinity-purified AP-1 were carried out in the presence of $10 \mu \mathrm{g}$ BSA. Binding assays with in vitro translated proteins were carried out in the presence of 0.2 $\mu \mathrm{g}$ poly[d(I-C)] $0.5 \mu \mathrm{g}$ of single-stranded DNA. Protein-DNA complexes were resolved on $5 \%$ polyacrylamide gels $(30: 1$ acrylamide/bis-acrylamide] in $0.5 \mathrm{TBE}$ [ $1 \times \mathrm{TBE}, 50 \mathrm{mM}$ Tris borate ( $\mathrm{pH} 8.5$ ), 1 mM EDTA].

\section{In vitro transcription and translation}

Human IUN cDNA (a gift from Dr. Eric Fodor) and rat FOS cDNA were subcloned into pGEM3. The plasmids were linearized with appropriate restriction enzymes and were transcribed in vitro, using Sp6 RNA polymerase in the presence of $\mathrm{m}^{7} \mathrm{GpppG}$. RNA was extracted by phenol/chloroform and precipitated with ethanol. Approximately $5 \mu \mathrm{g}$ of RNA was translated in vitro, using $35 \mu \mathrm{l}$ of micrococcal nuclease-treated rabbit reticulocyte lysate, as recommended by the supplier (Promega Biotec). One $\mu$ l of the translation mixture was used in the DNA-binding assays.

\section{Antibodies}

Monoclonal antibody 411 to amino acids $4-17$ of FOS protein was purchased from Microbiological Associates (Bethesda, Maryland). Affinity-purified antibodies to the $M$ peptide (amino acids 127-152 of FOS protein; Curran et al. 1985) were a gift from Tom Curran (Roche Institute of Molecular Biology, Nutley, New Jersey). Affinity-purified antibodies to the carboxyl terminus of human MYC protein were a gift from Gary Ramsay (Ramsay et al. 1984). Inhibition of protein-DNA complex formation with antibodies was performed by adding antibodies as described by Distel et al. (1987).

\section{Immunoprecipitation of labeled FSE2 and MYC-NRE}

Nuclear extracts $(10-20 \mathrm{mg} / \mathrm{ml})$ were preadsorbed with an equal volume of protein $\mathrm{A} /$ Sepharose in buffer $\mathrm{A}$ for $1 \mathrm{hr}$ at $4^{\circ} \mathrm{C}$. The Sepharose beads were collected by centrifugation, and the supernatant was used for the binding assay. Antibodies were preadsorbed with protein $\mathrm{A} / \mathrm{Sepharose}(1 \mu \mathrm{l}$ of antibodies with $30 \mu \mathrm{l}$ of beads) for $1 \mathrm{hr}$ at $4^{\circ} \mathrm{C}$. The beads were washed twice in $30 \mathrm{~mm} \mathrm{NaCl}, 0.1 \% \mathrm{NP}-40,10 \mathrm{mM}$ Tris $(\mathrm{pH} 8.0)$, and $0.5 \mathrm{~mm}$ EDTA. The protein-DNA complexes were formed with the preadsorbed extracts and labeled double-stranded oligonucleotides as described above. After preadsorption with protein A/ Sepharose, antibodies were incubated with the protein-DNA complexes for $1 \mathrm{hr}$ at room temperature. The beads then were washed three times with $1 \mathrm{ml}$ of $50 \mathrm{mM} \mathrm{NaCl}, 0.1 \% \mathrm{NP}-40,10$ $\mathrm{mM}$ Tris (pH 8.0), and $0.5 \mathrm{~mm}$ EDTA. The labeled DNA was recovered from the beads by phenol/chloroform extraction and then was loaded on a $10 \%$ acrylamide gel (19:1 acrylamide to bis/acrylamide) in TBE containing $7 \mathrm{M}$ urea.

\section{Immunoblotting of protein-DNA complexes}

Protein-DNA complexes were formed with $2 \mu \mathrm{g}$ of unlabeled oligonucleotides and $100 \mu \mathrm{g}$ of nuclear extract as described above. Protein-DNA complexes were resolved on a native polyacrylamide gel and transferred to nitrocellulose in $30 \mathrm{~min}$ at $2.5 \mathrm{~mA} / \mathrm{cm}^{2}$ gel surface with a PolyBlot transfer apparatus (American Bionetics, Emeryville, California), using the transfer buffers described by the manufacturer. Then the filter was incubated for $1 \mathrm{hr}$ at room temperature in TBS [10 mM Tris- $\mathrm{HCl}$ [pH 8.0), $150 \mathrm{mM} \mathrm{NaCl}$ ], containing $5 \%$ calf serum, $2 \%$ nonfat milk, and $0.5 \%$ Tween 20 , followed by $2 \mathrm{hr}$ of incubation with FOS M peptide affinity-purified antibodies and ${ }^{125}$ I-labeled protein A (Burnette 1981).

\section{Acknowledgments}

We thank David Levens for sharing information and materials and for valuable discussions, Danielle Melloul for advice on preparation of nuclear extracts, Tom Curran for c-fos antibody, Beth Allegretto and Michael Karin for affinity-purified AP-1, Eric Fodor for the IUN cDNA, and Lynn Vogel for preparing the manuscript. Work summarized here was supported by the National Institutes of Health (grants CA-12705 and CA-44338) and by funds from the G.W. Hooper Research Foundation.

\section{Note added in proof}

The unpublished results of $M$. Takimoto and D. Levens mentioned throughout this paper are now in press. Takimoto, M. J.P. Quinn, R.A. Farina, L.M. Staudt, and D. Levens. 1989. Fos/ JUN and octamer binding protein interact with a common site in a negative element of the human c-myc gene. J. Biol. Chem. (in press).

\section{References}

Angel, P., M. Imagawa, R. Chiu, B. Stein, R.J. Imbra, H.J Rahmsdorf, C. Jonat, P. Herrlich, and M. Karin. 1987. Phorbol ester-inducible genes contain a common cis element recognized by a TPA-modulated trans-acting factor. Cell 49: 729-739.

Bentley, D.L. and M. Groudine. 1986. A block to elongation is largely responsible for decreased transcription of $\mathrm{c}-\mathrm{myc}$ in differentiated HL60 cells. Nature 321: 702-706.

- 1988. Sequence requirements for premature termination of transcription in the human c-myc gene. Cell $53245-$ 256.

Bohmann, D., T.J. Bos, A. Admon, T. Nishimura, P.K. Vogt, and R. Tjian. 1987. Human proto-oncogene c-jun encodes a DNA binding protein with structural and functional properties of transcription factor AP-1. Science 238: 1386-1392.

Burnette, W.M. 1981. 'Western blotting': electrophoretic transfer of proteins from sodium dodecyl sulphate-polyacrylamide gels to unmodified nitrocellulose and radiographic detection with antibody and radioiodinated protein A. Anal. Biochem. 112: 195-203.

Chiu, R., W.J. Boyle, J. Meek, T. Smeal, T. Hunter, and M. Karin. 1988. The c-fos protein interacts with c-jun/AP-1 to stimulate transcription of AP-1 responsive genes. Cell 54: 541-552.

Cochran, B.H., J. Zullo, I.M. Verma, and D.C. Stiles. 1984. Expression of the c-fos oncogene and of an fos-related gene is 
stimulated by platelet-derived growth factor. Science 226: 1080-1082.

Cohen, D.R. and T. Curran. 1988. fra-1: A serum-inducible, cellular immediate-early gene that encodes a fos-related antigen. Mol. Cell. Biol. 8: 2063-2079.

Cole, M.D. 1986. The myc oncogene: Its role in transformation and differentiation. Annu. Rev. Genet. 20: 361-384.

Cory, S. 1986. Activation of cellular oncogenes in hemopoietic cells by chromosome translocations. Adv. Cancer Res. 47: 189-234.

Curran, T. and B.R. Franza, Jr. 1988. Fos and Jun: The AP-1 connection. Cell 55: 393-397.

Curran, T., C. Van Beveren, N. Ling, and I.M. Verma. 1985. Viral and cellular fos proteins are complexed with a 39,000dalton cellular protein. Mol. Cell. Biol. 5: 167-172.

Dean, M., R.A. Levine, W. Ran, M.S. Kindy, G.E. Sonenshein, and J. Campisi. 1986. Regulation of c-myc transcription and mRNA abundance by serum growth factors and cell contact. J. Biol. Chem. 261: 9161-9166.

Dignam, J.D., P. Martin, B.S. Shastry, and R.G. Roeder. 1983. Eukaryotic gene transcription with purified components. Methods Enzymol. 101: 582-598.

Distel, R.J., H.-S. Ro, B.S. Rosen, D.L. Groves, and B.M. Spiegelman. 1987. Nucleoprotein complexes that regulate gene expression in adipocyte differentiation: Direct participation of c-fos. Cell 49: 835-844.

Eick, D. and G. Bornkamm. 1986. Transcriptional arrest with the first exon is a fast control mechanism in c-myc gene expression. Nucleic Acids Res. 14: 8331-8346.

Endo, T. and B. Nadal-Ginard. 1986. Transcriptional and posttranscriptional control of c-myc during myogenesis: Its mRNA remains inducible in differentiated cells and does not suppress the differentiated phenotype. Mol. Cell. Biol. 6: $1412-1421$.

Franza, B.R., Jr., F.J. Rauscher III, S.F. Josephs, and T. Curran. 1988. The fos complex and fos-related antigens recognize sequence elements that contain AP-1 binding sites. Science 239: $1150-1153$.

Fried, M. and D.M. Crothers. 1981. Equilibria and kinetics of lac repressor-operator interactions by polyacrylamide gel electrophoresis. Nucleic Acids Res. 9: 6505-6525.

Gonda, T.J. and D. Metcalf. 1984. Expression of myb, myc and fos proto-oncogenes during the differentiation of a murine myeloid leukaemia. Nature 310: 249-251.

Graham, F.L. and A.J. Van der Eb. 1973. A new technique for the assay of infectivity of human adenovirus 5 DNA. Virology 52: 456-467.

Greenberg, M.E. and E.B. Ziff. 1984. Stimulation of 3T3 cells induces transcription of the c-fos proto-oncogene. Nature 311: 433-438.

Greenberg, M.E., L.A. Greene, and E.B. Ziff. 1985. Nerve growth factor and epidermal growth factor induce rapid transient changes in proto-oncogene transcription in $\mathrm{PCl} 2$ cells. I. Biol. Chem. 260: 14101-14111.

Greenberg, J.E., A.L. Hermanowski, and E.G. Ziff. 1986. Effect of protein synthesis inhibitors on growth factor activation of c-fos, c-myc, and actin gene transcription. Mol. Cell Biol. 6: $1050-1057$.

Grosso, L.E. and H.C. Pitot. 1985. Transcriptional regulation of c-myc during chemically induced differentiation. Cancer Res. 45: 847-850.

Hay, J., J.M. Bishop, and D. Levens. 1987. Regulatory elements that modulate transcription from human c-myc. Genes Dev. 1: 659-671.

Kelly, J., B.H. Cochran, C.D. Stiles, and P. Leder. 1983. Cell-specific regulation of the $\mathrm{c}-m y c$ gene by lymphocyte mitogens and platelet-derived growth factor. Cell 35: 603-610

Lamph, W.W., P. Wamsley, P. Sassone-Corsi, and I.M. Verma. 1988. Induction of proto-oncogene IUN/AP1 by serum and TPA. Nature 334: 629-631.

Lee, W., P. Mitchell, and R. Tjian. 1987. Purified transcription factor AP-1 interacts with TPA-inducible enhancer elements. Cell 49: 741-752.

Levine, R.A., J.E. McCormack, A. Buckler, and G.E. Sonenshein. 1986. Transcriptional and posttranscriptional control of c-myc gene expression in WEHI 231 cells. Mol. Cell. Biol. 6: $4112-4116$.

Maniatis, T., E.F. Fritsch, and J. Sambrook. 1982. Molecular cloning: A laboratory manual. Cold Spring Harbor Laboratory, Cold Spring Harbor, New York.

Muller, R., R. Bravo, J. Burckhardt, and T. Curran. 1984. Induction of c-fos gene and protein by growth factors precedes activation of c-myc. Nature 312: 716-720.

Muller, R., T. Curran, D. Muller, and L. Guilbert. 1985. Induction of c-fos during myelomonocytic differentiation and macrophage proliferation. Nature 314: 546-548.

Nepveu, A., R.A. Levine, J. Campisi, M.E. Greenberg, E.B. Ziff, and K.B. Marcu. 1987. Alternative modes of c-myc regulation in growth factor-stimulated and differentiating cells. Oncogene 1: 243-250.

Ramsay, G., G.I. Evan, and J.M. Bishop. 1984. The protein encoded by the human proto-oncogene c-myc. Proc. Natl. Acad. Sci. 81: 7742-7746.

Ramsay, R.G., K. Ikeda, R.A. Rifkind, and P.A. Marks. 1986 Changes in gene expression associated with induced differentiation of erythroleukemia: Protooncogenes, globin genes, and cell division. Proc. Natl. Acad. Sci. 83: 6849-6853.

Rauscher, F.J., III, L. Sambucetti, T. Curran, R.J. Distel, and B.M. Spiegelman. 1988a. A common DNA binding site for fos protein complexes and transcription factor AP-1. Cell 52: $471-480$.

Rauscher, F.J. III, D.R. Cohen, T. Curran, T.J. Bos, P.K. Vogt, D. Bohmann, R. Tjian, and B.R. Franza, Jr. 1988b. FOS-associated protein $\mathrm{p} 39$ is the product of the jun proto-oncogene. Science 240: 1010-1016.

Sassone-Corsi, P., I.C. Sisson, and I.M. Verma. 1988a. Transcriptional auto regulation of proto-oncogene fos. Nature 334: 314-319.

Sassone-Corsi, P., W.W. Lamph, M. Kamps, and I.M. Verma. 1988 b. FOS-associated cellular p 39 is related to nuclear transcription factor AP-1. Cell 54: 553-560.

Schonthal, A., P. Herrlich, H.J. Rhamsdorf, and H. Ponta. 1988. Requirement for fos gene expression in the transcriptional activation of collagenase by other oncogenes and phorbol esters. Cell 54: 325-334.

Siebenlist, V., P. Bressler, and K. Kelly. 1988. Two distinct mechanisms of transcriptional control operate on c-myc during differentiation of HL60 cells. Mol. Cell. Biol. 8: 867874.

Small, M.B., N. Hay, M. Schwab, and J.M. Bishop. 1987. Neoplastic transformation by the human gene N-myc. Mol. Cell. Biol. 7: 1638-1645.

Strauss, F. and A. Varshavsky. 1984. A protein binds to a satellite DNA repeat at three specific sites that could be brought into mutual proximity by DNA folding in the nucleosome. Cell 37: 889-901.

Walker, M.D., T. Edlund, A.M. Boulet, and W.J. Rutter. 1983. Cell-specific expression controlled by the $5^{\prime}$ flanking region of insulin and chymotrypsin genes. Nature 306: 557-561.

Zajac-Kaye, M., E.P. Gelmann, and D. Levens. 1988. A point mutation in the c-myc locus of a Burkitt lymphoma abolishes binding of a nuclear protein. Science 240: 1776-1780. 


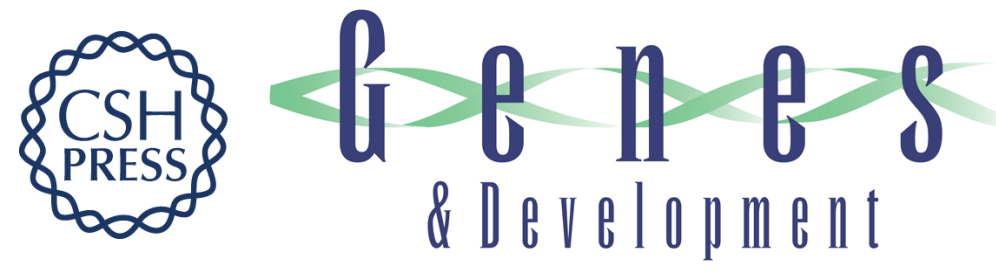

\section{A FOS protein is present in a complex that binds a negative regulator of MYC.}

N Hay, M Takimoto and J M Bishop

Genes Dev. 1989, 3:

Access the most recent version at doi:10.1101/gad.3.3.293

References This article cites 45 articles, 18 of which can be accessed free at:

http://genesdev.cshlp.org/content/3/3/293.full.html\#ref-list-1

License

Email Alerting Receive free email alerts when new articles cite this article - sign up in the box at the top Service right corner of the article or click here.

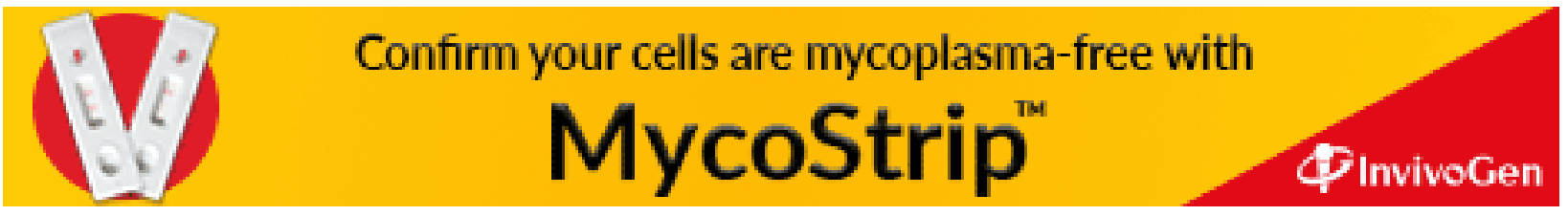

